\title{
Research in the field of evaluation of anfo explosive preparation installations, Tests and results
}

\author{
Stefan Ilici ${ }^{1}$, Edward Gheorghiosu ${ }^{1}$, Daniela Rus $^{1}$, and Ciprian Jitea ${ }^{1}$ \\ ${ }^{1}$ National Institute for Research and Development in Mine Safety and Protection to Explosion - \\ INSEMEX Petrosani, Department of Safety of Explosion and Pyrotechnic Articles, G-ral V. Milea \\ Street 32-34, Petrosani, Romania
}

\begin{abstract}
The technical-economic efficiency of rock extraction works depends significantly on the drilling and blasting works as well as the adjacent costs. The cost of the explosive is an important component in these and the generalization of the widespread use of the use of bulk explosives (ANFO) has generated a significant reduction in the cost. Making the explosive close to the place of use in fixed or semi-stationary installations on the quarry stage eliminates the costs related to storage or long-term storage, transport, escort, security. However, installations for the manufacture of ANFO type explosives must consistently produce a simple quality explosive mixture. The quality lies in the participation of the precursors as well as in the degree of homogenization, stability and a good behavior to external stimuli that can lead to sensibility to initiation stimuli or inhibition of sensitivity where the harmful influence of moisture in the raw material or environment must be emphasized. The paper presents tests and results obtained in recent years for such installations used by several companies in Romania performed under the supervision of INSEMEX specialists. These assessments were completed with the certification of explosives manufacturing facilities for the specified operating parameters as well as for explosives.
\end{abstract}

\section{Introduction}

An explosive material, or explosive substance, is a substance (or mixtures of substances) that is in a metastable state, capable of suffering under the action of heat or a mechanical factor, an explosive transformation that reacts rapidly, decomposes suddenly and violently with development. strong heat, light and gas, causing a large increase in pressure in its environment. Explosives for civilian use belong to the category of dangerous products, representing a significant risk of explosion when stored and handled under conditions of exposure to high temperatures. ANFO type explosives are low power explosives with a low sensitivity to external actions. The main risks associated with the use of explosives for civilian use are those of uncontrolled explosion, fire or poisoning with combustion products. The importance of the field is argued by the fact that for explosives for civilian use, the European Union has promoted Directive 2014/28 / EU, which regulates the placing on the market of these products. In the said Directive there is a technical requirement regarding the 
safety of explosives which must be assessed before placing on the market, by testing the products according to harmonized standards with the aim of ascertaining the conformity / non-compliance with the relevant safety requirements. These tests are performed in RENAR accredited test laboratories, based on harmonized European Standards. As a result, we mention some of the most important tests that were carried out within the INSEMEX Laboratories, having as object ANFO type explosives:

- Detection and measurement of toxic explosion gases;

- Determining the impact sensitivity of explosives and detonating cords;

- Verification of the friction sensitivity of the blasting explosives and the core of the detonating wicks;

- Determining the percentage participation of the precursors in the product made with a mobile / fixed explosive manufacturing unit.

- DETECTION AND MEASUREMENT OF TOXIC EXPLOSION GASES. This test is performed in a special stand called a gas chamber in which the test sample is inserted and detonated. Following this operation, the amount of gas resulting from the Testo $350 \mathrm{XL}$ plus testo easy Emission Software is measured. The results are listed in table no. 1 and are compared with the technical specification of the explosive.

Table 1

\begin{tabular}{|c|c|c|c|c|}
\hline Specifications & Unit & Test no. 1 & Test no. 2 & Test no. 3 \\
\hline $\begin{array}{l}\text { The volume of the explosion } \\
\text { chamber }\end{array}$ & $\mathrm{m}^{3}$ & \multicolumn{3}{|c|}{15} \\
\hline The amount of explosive & $\mathrm{kg}$ & 0.475 & 0.489 & 0.479 \\
\hline $\begin{array}{l}\text { The length of the explosive } \\
\text { column }\end{array}$ & $\mathrm{m}$ & 0.550 & 0.550 & 0.550 \\
\hline The means of initiation & - & \multicolumn{3}{|c|}{ Booster Type I + Electric detonator no. 8} \\
\hline $\begin{array}{l}\text { Initial temperature in the } \\
\text { explosion chamber }\end{array}$ & ${ }^{\circ} \mathrm{C}$ & 20 & 22 & 23 \\
\hline The amount of CO measured & ppm & 1038 & 929 & 856 \\
\hline The amount of $\mathrm{CO} 2$ measured & $\%$ & 0.77 & 0.76 & 0.74 \\
\hline The amount of NO measured & ppm & 326 & 290 & 250 \\
\hline The amount of NOx measured & ppm & 464 & 456 & 468 \\
\hline The amount of CO calculated & $1 / \mathrm{kg}$ & 32.77 & 28.49 & 26.80 \\
\hline The amount of $\mathrm{CO} 2$ calculated & $1 / \mathrm{kg}$ & 243.15 & 233.12 & 231.73 \\
\hline The amount of NO calculated & $1 / \mathrm{kg}$ & 10.29 & 8.89 & 7.82 \\
\hline The amount of NOx calculated & $1 / \mathrm{kg}$ & 14.65 & 13.98 & 14.65 \\
\hline The average amount of $\mathrm{CO}$ & $\mathrm{l} / \mathrm{kg}$ & \multicolumn{3}{|c|}{29.35} \\
\hline The average amount of $\mathrm{CO} 2$ & $\mathrm{l} / \mathrm{kg}$ & \multicolumn{3}{|c|}{ 236.00 } \\
\hline The average amount of $\mathrm{NO}$ & $\mathrm{l} / \mathrm{kg}$ & \multicolumn{3}{|c|}{9.00} \\
\hline The average amount of NOX & $\mathrm{l} / \mathbf{k g}$ & \multicolumn{3}{|c|}{14.42} \\
\hline
\end{tabular}



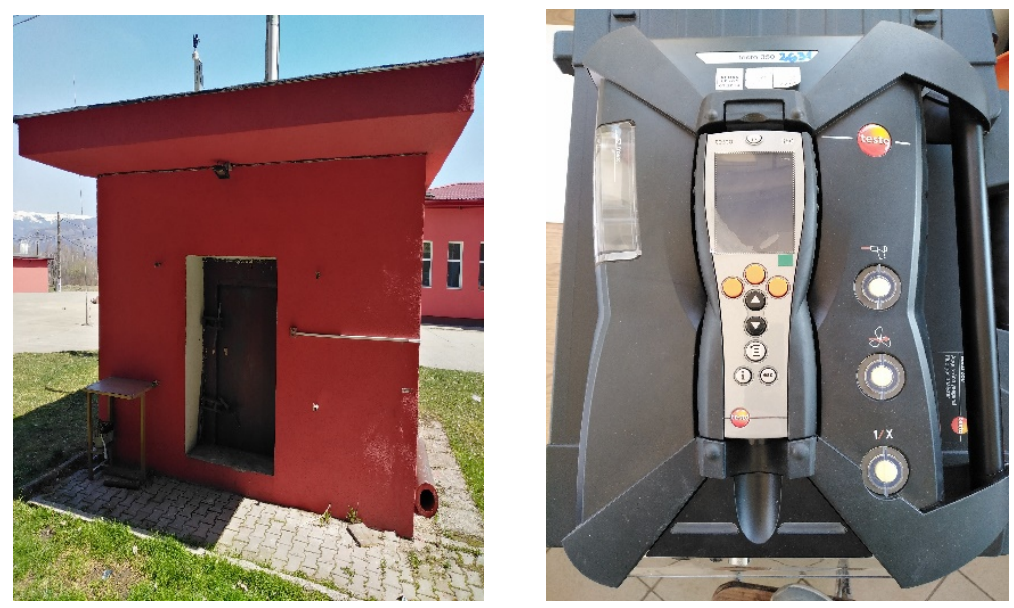

Photo 1. OVERVIEW OF THE STAGE FOR DETECTION AND MEASUREMENT OF EXPLOSIVE TOXIC GASES.

\section{Determination of the sensitivity to impact of explosives and detonating cords}

The impact sensitivity of explosives is a test of high importance in terms of explosive safety and is performed on the stand called BAM type hammer. The test consists of introducing a volumetrically measured quantity of ANFO type explosive between two pellets which in turn are inserted into the anvil of the test stand. Determine the minimum height specified by the manufacturer and release the weight, following whether or not a reaction has occurred. The positive result can be recorded as a result of an explosion noise with or without breaking the housing, but there can also be a specific smell of generated gas, light and when the assembly changes the color of the explosive material left in the situation of incomplete explosion. The results are listed in Tab. Nr. 2:

Tab.2

\begin{tabular}{|l|c|c|c|c|}
\hline $\begin{array}{c}\text { Nr. } \\
\text { Crt. }\end{array}$ & $\begin{array}{c}\text { Hammer } \\
\text { mass M, } \\
{[\mathrm{kg}]}\end{array}$ & $\begin{array}{c}\text { The height of } \\
\text { fall, } \mathrm{h}[\mathrm{m}]\end{array}$ & $\begin{array}{c}\text { Result: } \\
\mathrm{R}-\text { reaction; FR }-\mathrm{no} \\
\text { reaction }\end{array}$ & $\begin{array}{c}\text { Impact energy } \mathrm{Si}=\mathrm{M} \cdot \mathrm{h} \cdot \mathrm{g}, \\
{[\mathrm{J}],} \\
\mathrm{g}=10 \mathrm{~m} / \mathrm{s}^{2}\end{array}$ \\
\hline 1. & 5 & 0.20 & FR & 10.0 \\
\hline 2. & 5 & 0.30 & FR & 15.0 \\
\hline 3. & 5 & 0.40 & FR & 20.0 \\
\hline 4. & 5 & 0.50 & FR & 25.0 \\
\hline 5. & 5 & 0.60 & FR & 30.0 \\
\hline 6. & $\mathbf{5}$ & $\mathbf{0 . 7 0}$ & R & $\mathbf{3 5 . 0}$ \\
\hline 7. & $\mathbf{5}$ & $\mathbf{0 . 6 5}$ & $\mathbf{R}$ & $\mathbf{3 2 . 5}$ \\
\hline 8. & 5 & 0.60 & FR & 30.0 \\
\hline 9. & 5 & 0.60 & FR & 30.0 \\
\hline 10. & 5 & 0.60 & FR & 30.0 \\
\hline 11. & $\mathbf{5}$ & $\mathbf{0 . 6 0}$ & R & $\mathbf{3 0 . 0}$ \\
\hline 12. & $\mathbf{5}$ & $\mathbf{0 . 5 5}$ & R & 27.5 \\
\hline 13. & 5 & 0.50 & FR & 25.0 \\
\hline 14. & 5 & 0.50 & FR & 25.0 \\
\hline 15. & 5 & 0.50 & FR & \\
\hline
\end{tabular}




\begin{tabular}{|l|l|l|l|l|}
\hline 16. & $\mathbf{5}$ & $\mathbf{0 . 5 0}$ & $\mathbf{R}$ & $\mathbf{2 5 . 0}$ \\
\hline 17. & 5 & 0.45 & FR & 22.5 \\
\hline 18. & 5 & 0.45 & FR & 22.5 \\
\hline 19. & $\mathbf{5}$ & $\mathbf{0 . 4 5}$ & $\mathbf{R}$ & $\mathbf{2 2 . 5}$ \\
\hline 20. & $\mathbf{5}$ & $\mathbf{0 . 4 0}$ & $\mathbf{R}$ & $\mathbf{2 0 . 0}$ \\
\hline 21. & 5 & 0.35 & FR & 17.5 \\
\hline 22. & 5 & 0.35 & FR & 17.5 \\
\hline 23. & 5 & 0.35 & FR & 17.5 \\
\hline 24. & 5 & 0.35 & FR & 17.5 \\
\hline 25. & 5 & 0.35 & FR & 17.5 \\
\hline 26. & 5 & 0.35 & FR & 17.5 \\
\hline \multicolumn{5}{|c|}{ Impact sensitivity (J): 20.0} \\
\hline
\end{tabular}
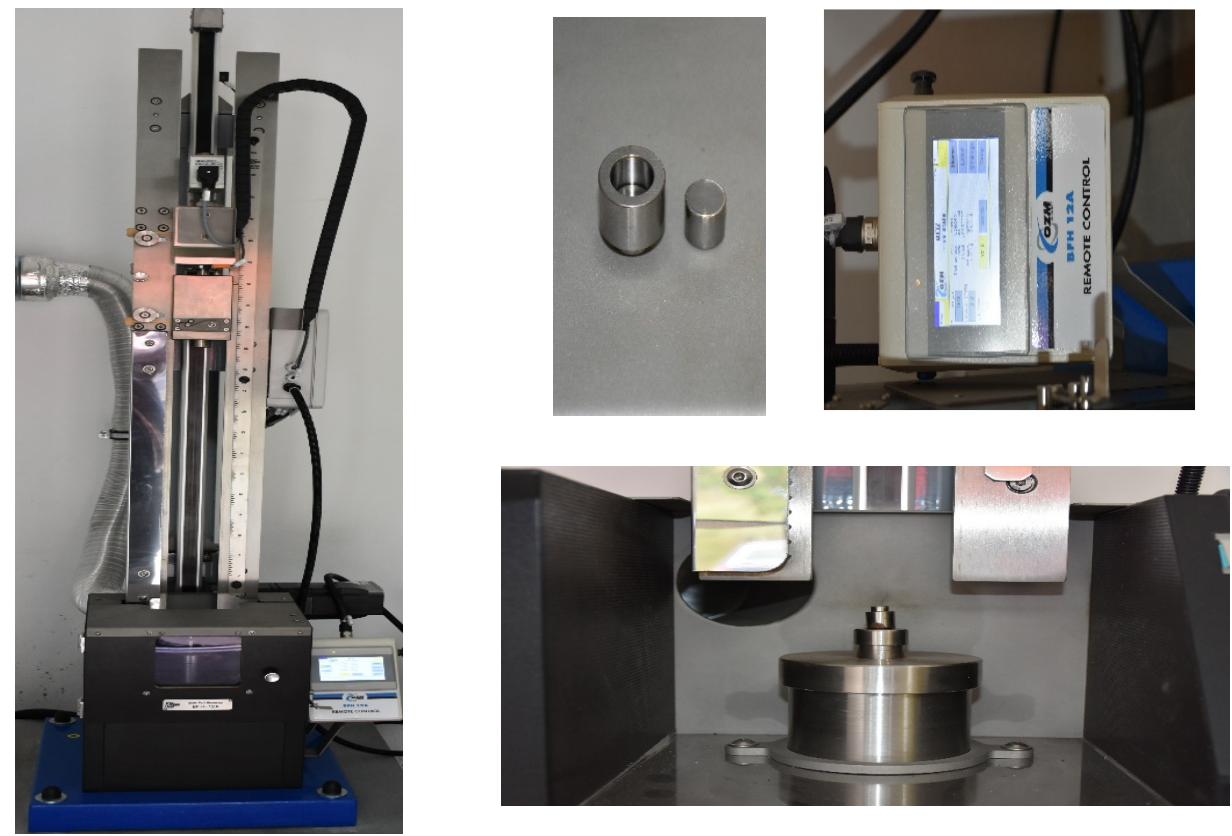

Photo 2. OVERVIEW OF THE STAND FOR DETERMINING THE IMPACT SENSITIVITY OF EXPLOSIVES AND DETONATING CORDS

\section{Checking the friction sensitivity of high explosives and core detonant cords}

The principle of the method is to determine the minimum frictional force for which a reaction occurs at 6 tests performed on the sample fixed on a porcelain plate having a horizontal translational motion. The force produced by a special device intended for this purpose (called JULIUS PETERS) is transmitted to the test piece by means of a porcelain pin fixed in the apparatus above the test piece. The results obtained after performing the test on the explosive under test are summarized in table no.3:

Table 3

\begin{tabular}{|c|c|c|c|}
\hline $\begin{array}{c}\text { Nr. } \\
\text { crt. }\end{array}$ & $\begin{array}{c}\text { Friction force } \\
(\mathrm{N})\end{array}$ & $\begin{array}{c}\text { Working } \\
\text { temperature }(\mathrm{T})\end{array}$ & $\begin{array}{c}\text { Result: } \\
\text { R-reaction; FR-no reaction. }\end{array}$ \\
\hline 1 & 360 & 20 & FR \\
\hline
\end{tabular}




\begin{tabular}{|l|l|l|l|}
\hline 2 & 360 & 20 & FR \\
\hline 3 & 360 & 20 & FR \\
\hline 4 & 360 & 20 & FR \\
\hline 5 & 360 & 20 & FR \\
\hline 6 & 360 & 20 & FR \\
\hline
\end{tabular}

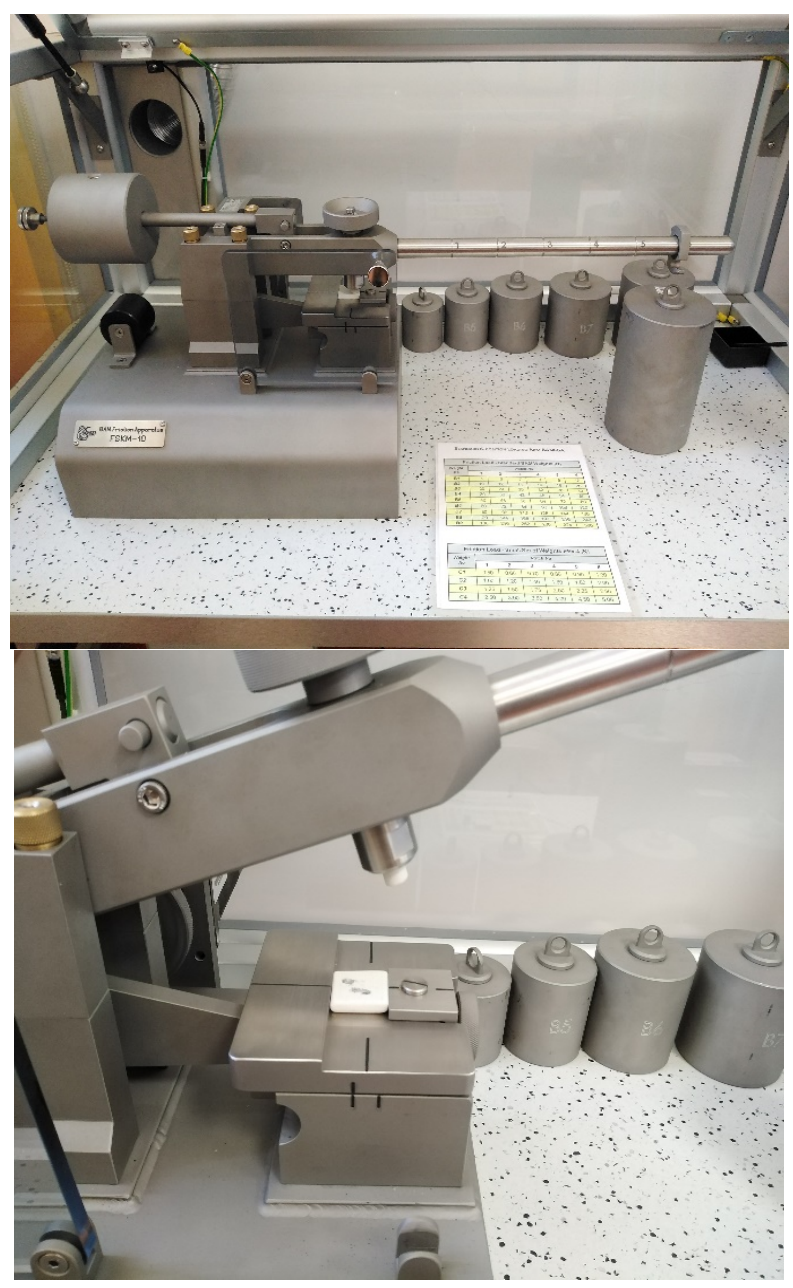

Photo 3. OVERVIEW OF THE STAND FOR CHECKING THE FRICTION SENSITIVITY OF BREAKING EXPLOSIVES AND THE CORE OF DETONATING CORDS

\section{Determination of the percentage participation of precursors in the made product with a mobile / fixed unit of explosive manufacture}

The principle of the method consists in making the mixture of porous ammonium nitrate and diesel made on a mobile or stationary installation. The frame subassemblies of an ANFO type explosive plant mounted on a MERCEDES BENZ truck chassis are:

- supply tank / bunker for porous ammonium nitrate;

- helical / auger conveyor, placed at the base of the supply bunker; 
- cellular dispenser;

- flexible pneumatic transport pipe of the ANFO explosive mixture in the boreholes;

- hydraulic drive unit;

- diesel injection circuit;

- compressed air supply group;

- command and control circuits.

Installation dimensions:

- length: $9000 \mathrm{~mm}$;

- height: $3200 \mathrm{~mm}$;

- width: $2500 \mathrm{~mm}$;

- capacity of the supply tank with porous granular ammonium nitrate: $10000 \mathrm{~kg}$;

- tank capacity for fuel component (diesel): 700 1;

Product description, technical characteristics:

ANFO explosive is a mixture of porous granular ammonium nitrate and diesel, manufactured in situ with a mobile explosive manufacturing unit (MEMU), intended for use in surface firing operations, in dry environments without water infiltration and in places without atmosphere. potentially explosive / flammable.

- composition:

- granular ammonium nitrate pores: $93 \div 96 \%$

- diesel: $4 \div 7 \%$; - density: $0.7-0.85 \mathrm{~g} / \mathrm{ml}$;

- sensitivity to impact:> $5 \mathrm{~J}$;

- sensitivity to friction:> $300 \mathrm{~N}$;

- humidity: $\max 1 \%$

- detonation speed $\geq 2000 \mathrm{~m} / \mathrm{s}$; (confined in a closed-ended steel pipe, inner diameter of $37.2 \mathrm{~mm}$, initiated with hexogen buster type I (according to SR EN 13631-12) with mass 20

$\pm 2 \mathrm{~g}$, diameter $20 \pm 2 \mathrm{~mm}$ ).

- thermodynamic properties:

- explosion temperature: $\min .2500 \mathrm{~K}$;

- explosion heat $\mathrm{V}=\mathrm{ct}: 3758.5 \div 4130.59 \mathrm{~kJ} / \mathrm{kg}$;

- oxygen balance: $-5.683 \div+5.324 \%$;

- volume of explosion gases: $960 \div 980 \mathrm{l} / \mathrm{kg}$;

- gas pressure: $759.03 \div 863.57 \mathrm{MN} / \mathrm{m}^{2}$;

- initiation: booster / explosive charge and electric detonator no. 8;

- resistance to negative / positive temperature: $1 \mathrm{~h}$ at $-10^{\circ} \mathrm{C} / 1 \mathrm{~h}$ at $+35^{\circ} \mathrm{C}$.

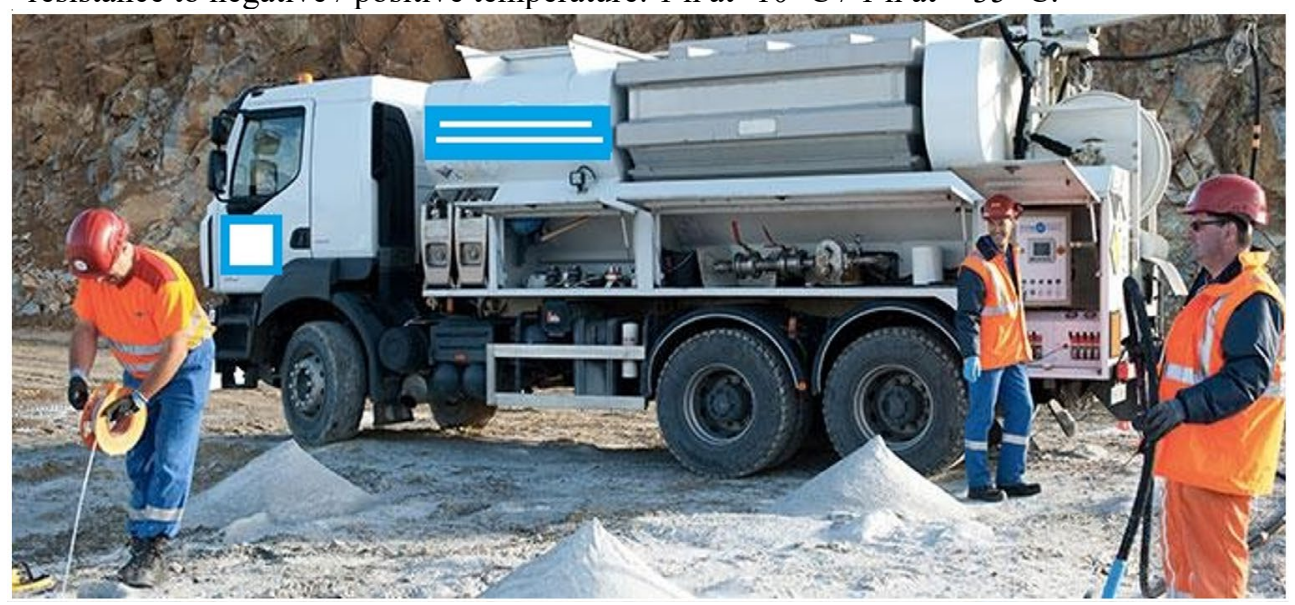

Photo 4. OVERVIEW OF THE ANFO EXPLOSIVE MANUFACTURING PLANT 
Following the tests and verifications established on the ANFO type explosive, it is established whether the explosive meets all the essential safety requirements, being granted its certification and its placing on the market as well as the certification of the installation for the manufacture of the simple ANFO type explosive mixture. The results of the tests on the explosive and the checks carried out on the installation for the manufacture of the mixture are given in the following documents: Explosive examination certificate (model);

\begin{tabular}{|c|c|}
\hline NATIONAL RESEARCH AND & INSEMEX 1809 \\
DEVELOPMENT INSTITUTE FOR & OEC- SECEMTI \\
MINING SAFETY AND EXPLOSIVE & EXPLOSIVES NOTIFIED \\
PROTECTION & BODY \\
& -INSEMEX-
\end{tabular}

INSEMEX GENERAL MANAGER

(signature)

EXPLOSIVES FOR CIVIL USE

\section{CERTIFICATE OF CONFORMITY TO TYPE}

2. INSEMEX.1809.EXP.xxx/21C2

3. The product / No. lot / Date of manufacture: Explosive ANFO / 1/2021

4. Applicant: S.C. ROMANIA S.R.L., pp. -, no. -, jud.-. Contract no. xxxx / 2021.

5. Manufacturer: S.C. ROMANIA S.R.L., pp. -, no. -, jud.-.

6. Address of the application for which the certification is made: Manufacturing point, Hunedoara county;

7. Product description: ANFO is a granular explosive consisting of a mixture of porous ammonium nitrate and diesel, intended for use in dry environments without water infiltration and without danger of explosion / fire.

8. The conformity of the product was assessed according to Annex III to Directive 2014/28 / EU and Annex no. 3 to GD 197/2016, Module C 2 and PSp-16 SECEMTI.

9. INSEMEX - SECEMTI notified with identification number 1809, declares for this product that conformity with the type described in the Examination Certificate - EU type INSEMEX has been established.1809.EXP.061 / 18, issued on 13.12.2018, Additional 1 INSEMEX.1809.EXP.061 / 18-1, issued on 10.12.2019 by INSEMEX - SECEMTI and with the applicable essential safety requirements defined in Annex II to Directive 2014/28 / EU, respectively Annex no. 2 the H.G. 197/2016. 10.Reference documents: EU examination certificate INSEMEX.1809.EXP.061 / 18; Additional 1 INSEMEX.1809.EXP.061 / 18-1; Evaluation report no. 099 / 22.02.2021.

11.This Certificate is issued to the applicant in point 4 , for the type of product in point 3 , manufactured at the address referred to in point 6 and may be reproduced only in its entirety without any modification.

12. The marking of the product must include the following: CE 1809 The explosives shall be placed on the market in the European Community on the basis of the CE conformity marking, followed by the identification number of the notified body INSEMEX SECEMTI, in accordance with the "Regulation for the affixing of the conformity marking and identification number" RAM, ed.3, rev.1, from January 2018, 11 pages +4 annexes), sent to the applicant.

Date of issue:

Validity:

Head of INSEMEX-OEC

Head of

INSEMEX-SECEMTI 
MINISTRY OF RESEARCH, INNOVATION AND DIGITALIZATION

NATIONAL RESEARCH INSTITUTE - DEVELOPMENT FOR MINING SAFETY AND ANTI-EXPLOSIVE PROTECTION - INSEMEX PETROSANI

Address: Str. Gender. V. Milea, no. 32-34, Code 332047, Petrosani, Hunedoara County Romania; Goal. (+4) 0254541 621, 0254541 622; Fax. (+4) 0254546 277; 0254541561

Nr.Reg.Com. J20 / 1504/1992, CUI 2664676; IBAN: RO18RNCB0165020175140001

BCR Petrosani; E-mail: insemex@insemex.ro; http: // www.insemex.ro / Page 1/1 Installation examination certificate (model)

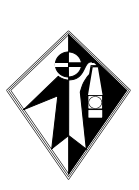

\author{
INCD-INSEMEX PETROSANI EXPLOSIVES \\ CERTIFICATION SERVICE, MEANS SHOOTING AID \\ AND TECHNIQUES \\ - INSEMEX SECEMTI -
}

INSEMEX GENERAL MANAGER

(signature)

\title{
INCD- PETROŞANI SERVICIUL PENTRU CERTIFICARE EXPLOZIVI, MIJLOACE AJUTĂTOARE ŞI TEHNICI DE ÎMPUȘCARE
}

(1) CERTIFICATE OF CONFORMITY

(2) Certificate of conformity INSEMEX SECEMTI - CCm Nr. xxx / 2021.

(3) This certificate is issued for: The plant for the manufacture of ANFO explosives, at the place of use (location of blasting).

(4) Certification applicant4.1 / holder4.2:

(4.1) and (4.2) S.C. ROMANIA S.R.L., pp. --, no. -, jud.--

(5) The installation for the manufacture of ANFO explosives, described in the Annex to this certificate of conformity and in the descriptive documents cited therein, shall comply with the applicable legislation and the relevant applicable technical framework requirements as follows:

- Law 126/1995 on the regime of explosives, with subsequent amendments and completions;

- Technical Norms - to Law 126/1995, on the possession, preparation, experimentation, destruction, transport and storage, handling and use of explosives in any other specific operations in the activities of the holders, as well as the authorization of fireworks and pyrotechnicians. ", with subsequent amendments and completions.

- Decision no. 536/2002 for the approval of the Technical Norms on the possession, preparation, experimentation, destruction, transport, storage, handling and use of explosive materials used in any other specific operations in the activities of the holders, as well as the authorization of fireworks and pyrotechnics, as subsequently amended and supplemented ;

- Law 319/2006 on safety and health at work;

- Methodological Norms - from 11.10.2006 - for the application of the provisions of the Law on safety and health at work no. 319/2006;

- SR EN 13631-1 Explosives for civil use, Explosive explosives, Part 1 - Requirements;

- Framework technical requirements approved by the Scientific Council of INSEMEX Petroşani with approval report no. 31 / 10.09.1999.

- Good practice guide for the storage, transport and use of explosives. (PSp-12).

(6) Marking: Not applicable. A copy of this certificate must be in good condition in the tractor cab. 
(7) The holder / owner of the installation, to which this certificate refers, is responsible for compliance with the specifications and specifications in the ANNEX. Any modification to the installation shall be made only with the prior written consent of the body which issued this certificate.

(8) This certificate is valid for three years from the date of issue, unless it is suspended or withdrawn in advance if it is found that the holder or the product no longer meets the certification requirements. This certificate is legally valid only with the official address INCD-INSEMEX, may be used only for the product referred to in point 3, only for the applicant with the address referred to in point 4 and may be reproduced only in its entirety without any modification.

VALID: 2022.

HEAD OF INSEMEX SECEMTI

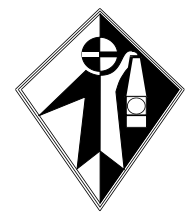

\author{
INCD-INSEMEX PETROSANI EXPLOSIVES \\ CERTIFICATION SERVICE, MEANS SHOOTING AID \\ AND TECHNIQUES \\ - INSEMEX SECEMTI -
}

INSEMEX SECEMTI CCm CERTIFICATE OF CONFORMITY Nr. xxx / 2021. Attached (A.1.1.) DESCRIPTION: The plant for the manufacture of ANFO explosives is mounted on a MERCEDES BENZ truck chassis, no. identification number HMME4xxxxxxxxx / 1976, registration number RO-29-xxx.

The frame subassemblies of the installation are:

- supply tank / bunker for porous ammonium nitrate;

- helical / auger conveyor, placed at the base of the supply bunker;

- cellular dispenser;

- flexible pneumatic transport pipe of the ANFO explosive mixture in the boreholes;

- hydraulic drive unit;

- diesel injection circuit;

- compressed air supply group;

- command and control circuits.

Installation dimensions:

- length: $9000 \mathrm{~mm}$;

- height: $3200 \mathrm{~mm}$;

- width: $2500 \mathrm{~mm}$;

- capacity of the supply tank with porous granular ammonium nitrate: $10000 \mathrm{~kg}$;

- tank capacity for fuel component (diesel): 7001 ;

(A.1.2.) REPORT NUMBERS: GLI test report no. 5083 / 18.03.2019.

(A.2.1.) REFERENCE DOCUMENTS AVAILABLE TO THE APPLICANT

- Description and user manual of a semimobile auto for the preparation of the ANFO explosive;

- Abbreviated user manual of a car dealer for the preparation of ANFO explosives;

- Instructions for use and labor protection measures during the operation of the installation, intended for the preparation and mechanized loading of the ANFO explosive at the place of use;

- Technical Specifications for ANFO Explosive: Nr. 101 Rev.0 / 25.09.2018, Ed.0 / 25.09.2018;

- Vehicle identity document H268852.

(A.2.2.) CONDITIONS OF SAFE USE:

- The holding company will elaborate a standardized form of "Work permit" which will include the list of checks of the tractor and the installation. 
- Before each use it is mandatory to issue a "Work Permit" which will clearly include the name of the person responsible for checking the condition of the truck and installation, the person responsible for carrying out the shooting work, the operators and which will be signed by each. Each "Work Permit" issued will specify the results of the checks of the truck and the installation, and will be approved by a person appointed in writing by the company's management.

- In case the installation travels on public roads to different locations, the truck will have to be certified according to the regulations for road transport.

- The personnel serving the installation will be equipped with personal protective equipment and anti-static underwear, certified for working with explosive materials.

- The personnel serving the installation will be trained and examined annually regarding the "Working instructions and labor protection measures for the operation of the installation which must be permanently found in the truck cab.

- The flexible pipe for the pneumatic transport of the explosive will be of antistatic type according to the norms in force.

- Any intervention at the installation with open flame is forbidden, if there is porous granular ammonium azoate in the supply tank.

- It is forbidden to operate the installation with defective measuring, control and command devices.

- The maintenance of the installation will be performed in accordance with the manufacturer's / manufacturer's recommendations. These records will be kept at the parking place, in a single register paginated, stringed and stamped on each page. This register will be verified monthly by the person appointed in writing by the management of the unit as having attributions regarding the approval of the "Work Permit", which will record under signature the result of the verifications.

- The records regarding the quantities of ANFO explosive manufactured and used, will comply with the legislation in force regarding the regime of explosives.

- It is forbidden to use the installation without having issued and approved the "Work Permit".

- The quantities of raw materials (porous granular ammonium nitrate and diesel) used in the manufacture of a batch as well as the resulting quantity of explosive will be recorded under signature by the person who orders the manufacture of batches of explosive (designated by the management of the unit) and the firecracker with the manufacture / use of the explosive, in a manufacturing report, which will be registered, dated, filed and kept in accordance with the regulations in force regarding the special regime documents.

- A copy of the "Certificate of Conformity" in force must be permanently in the cab of the truck.

This certificate may be reproduced only in its entirety and without any modification, including the Annex.

\section{Conclusions}

The quality of ANFO-type explosives manufactured in the field close to the place of use depends on a number of factors such as the quality of the raw materials (ammonium nitrate and mineral oil), the degree of homogenization which must be as high as possible, the correct dosage close to the composition of which the mixture of fuel and oxidant to react completely. This reaction, if carried out by a mixture of suitable quality, will occur at an explosion rate of more than $2200-2500 \mathrm{~m} / \mathrm{s}$ and with a high emission of gases which perform the mechanical work of demolition at a significant pressure. This desideratum is achieved if the adjustment for the quantitative dosage and the homogenization is kept under control, ie the 
MEMU type machine has the corresponding adjustments and periodic revisions, ensures the maintenance in time in the parameters. In order to ensure the quality of the ANFO type explosive, periodic tests must be carried out both in terms of the prepared explosive and the operating parameters of the machine.

\section{Bibliography}

1. Bauer I.A., Calder P. - New Guidelines for Explosives, Punching, and Shooting - C.I.M. Bulletin 2/1974.

2. Fodor D., Engineering of material shootings and work techniques. NAMASTE SI INFOMIN Publishing House 2007.

3. SR EN 13631-1 Explosives for civil use, Explosive explosives, Part 1 - Requirements;

4. Test Procedure PI-83 Verification of the friction sensitivity of blasting explosives and the core of detonating wicks;

5. Test Procedure PI-84 Determination of the impact sensitivity of explosives and detonating wicks;

6. Test Procedure PI-102 Detection and measurement of explosion toxic gases;

7. Test Procedure PI-101 Determining the percentage participation of the precursors in the process performed with mobile / fixed explosive manufacturing unit.

8. Directive 2014/28 / EU of the European Parliament and of the Council of 26 February 2014 on the harmonization of the laws of the Member States relating to the making available on the market and control of explosives for civil use, transposed by Government 